\title{
Analisis Pengaruh Brand Image, Harga, Dan Kualitas Produk Terhadap Keputusan Pembelian Mobil (Studi Kasus Mobil LCGC di Surakarta)
}

\author{
Budi Istiyanto ${ }^{1}$, Lailatan Nugroho ${ }^{2}$ \\ Sekolah Tinggi Ilmu Ekonomi Surakarta \\ budisties@gmail.com1, lailatan.nugroho@gmail.com
}

Diserahkan: 20 Oktober 2016, Diterima: 15 Desember 2016

\begin{abstract}
This study aimed to determine the effect of variable brand image, price, quality of product to decision of purchasing a car LCGC (Low Cost Green Car), either partial or jointly and to find among variables brand image, price, and quality of products which are larger role in influencing purchasing decisions LCGC car. Data collection techniques researchers did by observation and questionnaires directly by visiting the object of the research is to consumers who have made a purchase decision, especially type Agya LCGC car, AYLA, and Karimun Wagon R in Surakarta which would then be sampled. The data have been collected and tabulated and analyzed using multiple regression analysis.The results showed that the variables that significantly affect purchasing decisions is price and quality of products. While the variable Brand Image does not affect significantly. While the variables that affect predominantly variable price.
\end{abstract}

Keyword: Brand Image, Price, Quality Product, Purchase Decision

\begin{abstract}
Abstrak
Penelitian ini bertujuan untuk mengetahui pengaruh antara variable brand image, harga, dan kualitas produk terhadap keputusan pembelian mobil LCGC (Low Cost Green Car) baik secara partial maupun secara bersama-sama dan untuk mengetahui diantara variable brand image, harga, dan kualitas produk mana yang lebih berperan dalam mempengaruhi keputusan pembelian mobil $L C G C$. Teknik pengumpulan data peneliti lakukan dengan cara observasi dan penyebaran kuisioner secara langsung dengan cara mendatangi obyek penelitian yaitu kepada konsumen yang telah melakukan keputusan pembelian mobil $L C G C$ terutama type $A G Y A, A Y L A$, dan Karimun Wagon $R$ di wilayah Surakarta yang selanjutnya akan dijadikan sampel. Data yang telah terkumpul kemudian ditabulasi dan diolah dengan menggunakan analisis regresi berganda.

Hasil penelitian menunjukkan bahwa variabel yang mempengaruhi secara signifikan keputusan pembelian adalah harga dan kualitas produk. Sedangkan variabel Brand Image tidak mempengaruhi secara signifikan. Sedangkan variabel yang berpengaruh secara dominan adalah variabel harga.
\end{abstract}

Kata kunci: Brand Image, Harga, Kualitas Produk, Keputusan Pembelian

\section{A. PENDAHULUAN}

Otomotif adalah salah satu industri terbesar di Indonesia saat ini. Industri ini berkontribusi pada trilyunan rupiah pendapatan nasional tiap tahunnya serta membuka lapangan pekerjaan bagi ribuan pekerja kita. Dengan derasnya isu lingkungan hidup serta menipisnya persediaan minyak bumi kita, perkembangan mobil mengarah pada pembuatan mobil dengan biaya murah dan ramah lingkungan atau yang kita kenal dengan LCGC.

Dalam kaitan tersebut, Kementerian Perindustrian (Kemenperin) telah menerbitkan kebijakan mengenai mobil murah dan ramah lingkungan atau low cost green car (LCGC) yang tertuang dalam Peraturan Menteri Perindustrian No. 33/M-IND/PER/7/2013 tentang Pengembangan Produksi Kendaraan Bermotor Roda Empat yang Hemat Energi dan Harga Terjangkau. Penerbitan Permenperin No.33/2013 dimaksudkan untuk terus mendorong dan mengembangkan kemandirian industri otomotif nasional, khususnya industri komponen kendaraan bermotor roda empat agar mampu menciptakan motor penggerak, transmisi dan axle yang berdaya saing seiring dengan peningkatan permintaan kendaraan bermotor yang hemat energi dan harga terjangkau. "Pengembangan produksi mobil LCGC merupakan Program Pengembangan Produksi Kendaraan Bermotor dengan pemberian fasilitas berupa keringanan Pajak Pertambahan Nilai atas Barang Mewah (PPnBM)". Selain fasilitas tersebut Low Cost Green Car (LCGC) mempunyai beberapa kriteria, antara lain adalah: 1). Mempunyai harga sekitar 50 juta untuk daerah pedesaan dan 85 juta untuk pengguna umum. 2). Mempunyai efisiensi 
bahan bakar minimal $20 \mathrm{~km} /$ liter. 3). Mempunyai kandungan lokal minimal $65 \%$ dari seluruh komponen.

Komitmen pemerintah serta dukungan dari Pabrikan Mobil harus disesuaikan juga dengan perilaku dan daya beli masyarakat Indonesia. Banyak faktor yang mempengaruhi keputusan pembelian mobil, dalam penelitian ini merujuk pada konsumen yang ada di Kota Surakarta, dengan mempertimbangkan Brand Image, Harga, dan Kualitas Produk.

\section{B. KAJIAN PUSTAKA Brand Image}

Brand Image atau citra merek merupakan serangkaian sifat tangible dan intangible, seperti ide, keyakinan, nilai-nilai, kepentingan, dan fitur yang membuatnya menjadi unik (Hasan, 2013:210). Secara visual dan kolektif, sebuah brand image harus mewakili semua karakteristik internal dan eksternal yang mampu mempengaruhi bagaimana sebuah merek itu dirasakan oleh target pasar atau pelanggan.

Brand Image yang positif bisa dibangun dengan program Marketing yang kuat terhadap produk-produk yang memiliki keunikan dan menonjol dibandingkan dengan produk pesaing. Faktor pendukung terbentuknya Brand image dalam keterkaitannya dalam asosiasi merek (Keller, 2003: 167) adalah: 1) Keunggulan asosiasi merek (favorability of brand association), 2) Kekuatan asosiasi merek (Strength of brand association), 3) Keunikan asosiasi merek (Uniqueness of brand association)

\section{Harga}

Harga bisa diartikan sebagai jumlah uang (satuan moneter) dan/atau aspek lain (nonmoneter) yang mengandung utulitas/kegunaan tertentu yang diperlukan untuk mendapatkan sebuah produk (Tjiptono, 2012:315).Harga merupakan komponen yang sangat penting dalam kegiatan pemasaran. Karena apabila konsumen akan membeli suatu produk, maka harga dari produk tersebut sangat diperhatikan. Pada umumnya konsumen akan memilih harga yang lebih rendah dengan kualitas produk yang sama. Harga adalah sejumlah uang yang ditagihkan atas suatu produk atau jasa, atau jumlah dari nilai yang ditukarkan para pelanggan untuk memperoleh manfaat dari memiliki atau menggunakan suatu produk atau jasa. (Kotler dan Amstrong, 2008:345)

\section{Tujuan Penetapan Harga}

Dalam menentukan kebijaksanaan penetapan harga seseorang manajer harus menentukan apa yang menjadi alasan penetapan harga tersebut. Menurut Suratno dan Rismiati (2006: 215) ada beberapa tujuan penetapan harga antara lain yaitu : Mempertahankan kelangsungan hidup (survival), memaksimalkan laba jangka pendek, unggul dalam bagian pasar, unggul dalam kualitas produk.

\section{Faktor-faktor yang Mempengaruhi Keputusan Harga}

Keputusan tentang harga yang baik adalah apabila mampu mencerminkan seluruh kepentingan perusahaan, oleh karena itu perusahaan harus paham betul faktor-faktor yang secara langsung akan mempengaruhi tingkat harga yang akan ditentukan (Hasan, 2013:527). Adapun faktor-faktor tersebut adalah: 1) Kondisi perekonomian, 2) Tujuan Perusahaan, 3) Faktor legal dan Etis, 4) Bauran Pemasaran, 5) Biaya, 6) Ukuran Bisnis, 7) Persaingan, 8) Sifat Pasar, 9) Karakteristik Produk, 10) Permintaan dan Penawaran

\section{Pengertian Kualitas Produk}

Kualitas produk merupakan bentuk penilaian atas produk yang akan dibeli, apakah sudah memenuhi apa yang diharapkan konsumen (Angipora,2002:162). Definisi lain kualitas adalah suatu kondisi dinamis yang berhubungan dengan produk, jasa, manusia, proses, dan lingkungan yang memenuhi atau melebihi harapan (Tjiptono,2006:51). Menurut Cannon, dkk (2008:286), kualitas adalah kemampuan produk untuk memuaskan kebutuhan atau keinginan pelanggan. Menurut Simamora (2001:8), kualitas produk merupakan selisih produk yang layak menurut konsumen dengan produk menurut konsumen saat ini. Menurut Kotler dan 
Amstrong (2008:272) Kualitas produk adalah karakteristik produk atau jasa yang tergantung pada kemampuannya untuk memuaskan kebutuhan pelanggan yang dinyatakan atau diimplikasikan. Berdasarkan uraian tersebut, maka dapat disimpulkan bahwa kualitas adalah kemampuan suatu produk dalam memuaskan kebutuhan atau keinginan pelanggan.

\section{Dimensi Kualitas Produk}

Menurut Husein Umar (2003:37) Kualitas barang ditentukan melalui delapan dimensi sebagai berikut: Keistimewaan (Performance), Kelebihan (Feature), Kehandalan (Reability), Kesesuaian (Conformance), Daya tahan (Durability), Daya guna (Serviceability), Keindahan (Aesthetic), Respon (Fit and Finish).

\section{Keputusan Pembelian}

Proses pengambilan keputusan memainkan peran penting dalam memahami bagaimana konsumen secara actual mengambil keputusan pembelian. Para pemasar harus memahami setiap sisi perilaku konsumen (Kotler dan Keller, 2009:234). Proses pengambilan keputusan pembelian melalui lima tahap: Pengenalan masalah, pencarian informasi, evaluasi alternative, keputusan pembelian, dan perilaku pasca pembelian.

Faktor situasional yang tak terduga seperti berubahnya faktor pendapatan, harga atau keuntungan yang diharapkan akan mempengaruhi keinginan terhadap pembelian suatu produk. Namun demikian apabila seorang konsumen telah memutuskan untuk membeli, konsumen akan membuat sub keputusan lainnya mengenai harga, waktu membeli dan cara pembayarannya. Akan tetapi proses pengambilan keputusan tidak selalu dilaksanakan menurut urutan di atas, karena tergantung dari produk yang akan dibeli dan apakah pemuasan kebutuhan bersifat mendesak atau tidak.

Setelah membeli suatu produk, konsumen akan mengalami beberapa tingkatan kepuasan dan ketidakpuasan. Kepuasan dan ketidakpuasan terhadap suatu produk akan mempengaruhi tingkah laku berikutnya, yaitu kemungkinan pembelian ulang atau kebalikannya. Dalam arti jika konsumen merasa puas untuk selanjutnya mereka akan memperlihatkan peluang membeli yang lebih besar pada kesempatan berikutnya.

\section{METODE PENELITIAN Model Penelitian}

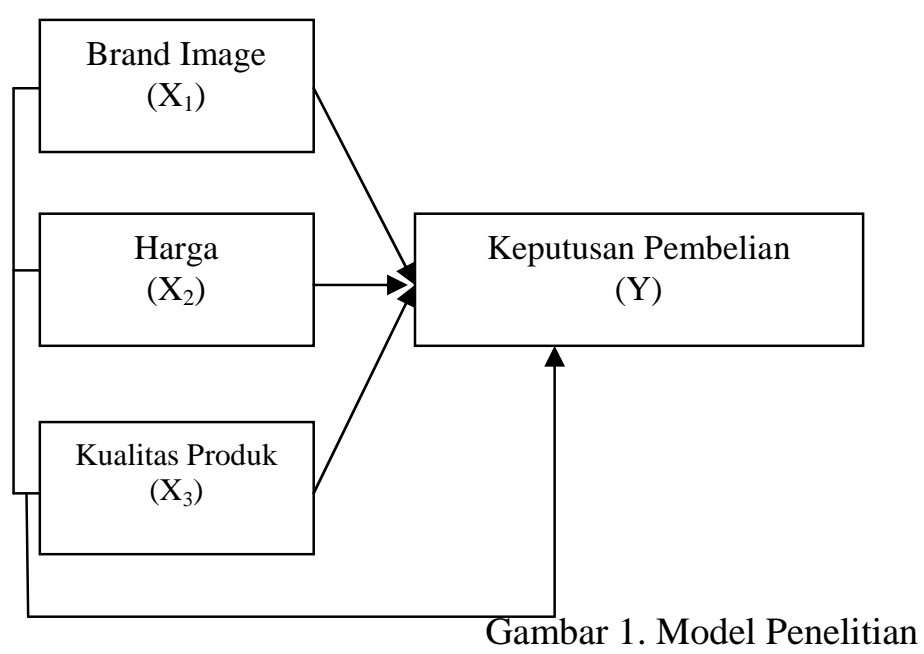

\section{Teknik Pengambilan Sampel}

Teknik pengambilan sampel yang digunakan adalah Purposive sampling atau disebut juga judgemental sampling yaitu pengambilan sampel berdasarkan "penilaian" (judgement) peneliti mengenai siapa-siapa saja yang memenuhi persyaratan untuk dijadikan sampel. Menurut Yusi dan Umiyati (2009:64), teknik sampling adalah cara untuk menentukan sampel 
yang jumlahnya sesuai dengan ukuran sampel yang akan dijadikan sumber data sebenarnya, dengan memperhatikan sifat-sifat dan penyebaran populasi agar diperoleh sampel yang repesentatif atau benar-benar dapat mewakili populasi. Adapun jumlah sampel akan di ambil dalam penelitian ini adalah 100 konsumen yang menggunakan mobil LCGC (Low Cost Green Car). Namun hanya 75 responden yang bersedia mengisi dan mengembalikan kuesioner tersebut. Tehnik pengambilan sampel di dalam penelitian ini adalah judgement sampling, dimana untuk memilih sampel diperlukan syarat-syarat tertentu. Syarat-syarat tersebut antara lain: konsumen yang menggunakan mobil LCGC dan saat itu berada di dealer toyota, suzuki dan Daihatsu di daerah penyebaran kuisioner hanya di Eks Karesidenan Surakarta.

\section{Teknik Analisis Data}

Teknik analisis Data dalam penelitian ini diawali dengan uji instrument berupa uji validitas dan reliabilitas untuk kuisioner yang digunakan dalam penelitian ini. Tabulasi data dari kuisioner responden yang terkumpul kemudian akan dianalisis dengan menggunakan analisis regresi linier berganda. Untuk pengujian dan pembuktian hipotesis menggunakan pengujian dengan uji t dan juga uji F. Uji t digunakan untuk menguji pengaruh variable brand image, Harga, dan Kualitas produk terhadap keputusan pembelian secara partial, dan uji F digunakan untuk menguji pengaruh variable Brand image, Harga, Kualitas produk secara bersama-sama terhadap keputusan pembelian mobil LCGC. Analisis adjusted $\mathrm{R}^{2}$ dilakukan untuk mengukur besar kemampuan menerangkan dari variabel independen terhadap variabel dependen dalam suatu model regresi.

\section{HASIL PENELITIAN DAN PEMBAHASAN}

\section{Uji Validitas dan reliabilitas}

Hasil perhitungan uji validitas terhadap kuisioner untuk variabel Brand Image (X1) terdapat 6 butir pernyataan dinyatakan 6 butir pernyataan valid.Hasil Reliability statistics untuk variabel Brand Image $\left(\mathrm{X}_{1}\right)$ menunjukkan Cronbanch's Alpha sebesar 0.881 > 0,6. Dengan demikian pernyataan dinyatakan reliabel, artinya terdapat konsistensi jawaban responden terhadap pernyataan kuesioner yang diajukan pada variabel Brand Image $\left(\mathrm{X}_{1}\right)$.

Hasil perhitungan uji validitas terhadap kuisioner untuk variabel Harga $\left(\mathrm{X}_{2}\right)$ terdapat 5 butir pernyataan dinyatakan valid. Hasil Reliability statistics untuk variabel Harga $\left(\mathrm{X}_{2}\right)$ menunjukkan Cronbanch's Alpha sebesar $0.893>0,6$. Dengan demikian pernyataan dinyatakan reliabel, artinya terdapat konsistensi jawaban responden terhadap pernyataan kuesioner yang diajukan pada variabel Harga (x2).

Hasil perhitungan uji validitas terhadap kuisioner untuk variabel Kualitas Produk (X3) terdapat 16 butir pernyataan dinyatakan valid.

Hasil Reliability statistics untuk Kualitas Produk $\left(\mathrm{X}_{3}\right)$ menunjukkan Cronbanch's Alpha sebesar $0.876>0,6$. Dengan demikian pernyataan dinyatakan reliabel, artinya terdapat konsistensi jawaban responden terhadap pernyataan kuesioner yang diajukan pada Variabel Kualitas Produk $\left(\mathrm{X}_{3}\right)$.

Hasil perhitungan uji validitas terhadap kuisioner untuk variabel Keputusan Pembelian (Y) terdapat 6 butir pernyataan dinyatakan valid. Hasil Reliability statistics untuk Keputusan Pembelian (Y) menunjukkan Cronbanch's Alpha sebesar $0.835>0,6$. Dengan demikian pernyataan dinyatakan reliabel, artinya terdapat konsistensi jawaban responden terhadap pernyataan kuisioner yang diajukan pada Variabel Keputusan Pembelian (Y).

\section{Persamaan Regresi Linier Berganda}

\begin{tabular}{|c|c|c|c|c|c|}
\hline \multirow[t]{2}{*}{ Model } & \multicolumn{2}{|c|}{$\begin{array}{l}\text { Unstandardized } \\
\text { Coefficients }\end{array}$} & Standardized & $\mathrm{T}$ & Sig. \\
\hline & $\mathrm{B}$ & Std. Error & Beta & & \\
\hline (Constant) & 9,782 & 3,509 & & 2,788 & ,007 \\
\hline
\end{tabular}




\begin{tabular}{rrrrrr}
\hline $\mathrm{X} 1$ &, 070 &, 103 &, 071 &, 678 &, 500 \\
\hline $\mathrm{X} 2$ &, 333 &, 121 &, 325 & 2,747 &, 008 \\
\hline $\mathrm{X} 3$ &, 155 &, 061 &, 313 & 2,544 &, 013 \\
\hline
\end{tabular}

Sumber: Data Primer diolah, 2016

Berdasarkan tabel diatas persamaan regresinya: $Y=\mathbf{9 , 7 8 2}+\mathbf{0 , 0 7 0} \mathbf{X}_{\mathbf{1}}+\mathbf{0 , 3 3 3 X _ { 2 }}+\mathbf{0 , 1 5 5} \mathbf{X}_{\mathbf{3}}$ Dari persamaan tersebut diketahui bahwa:

a. a = 9,782 adalah konstaanta. Artinya apabila variabel Brand Image (X1) sama dengan nol, maka Keputusan Pembelian (Y) adalah 9,782

b. Koefisien regresi Brand Image (X1) diperoleh sebesar 0,070 bernilai positif. Hasil tersebut menunjukkan bahwa setiap terjadi peningkatan Brand Image (X1) sebesar satu satuan maka akan diikuti oleh peningkatan Keputusan Pembelian (Y).

c. Koefisien regresi Harga (X2) diperoleh sebesar 0,333 bernilai positif. Hasil tersebut menunjukkan bahwa setiap terjadi peningkatan Harga (X2) sebesar satu satuan maka akan diikuti oleh peningkatan Keputusan Pembelian (Y).

d. Koefisien regresi Kualitas Produk (X3) diperoleh sebesar 0,155 bernilai positif. Hasil tersebut menunjukkan bahwa setiap terjadi peningkatan Kualitas Produk (X3) sebesar satu satuan maka akan diikuti oleh peningkatan Keputusan Pembelian (Y).

\section{Uji F}

Tabel 2. Hasil Uji F

ANOVA $^{\mathrm{a}}$

\begin{tabular}{|c|c|c|c|c|c|}
\hline Model & Sum of Squares & Df & Mean Square & F & Sig. \\
\hline Regression & 106,566 & 3 & 35,522 & 10,028 &, $000^{\mathrm{b}}$ \\
1 Residual & 251,514 & 71 & 3,542 & & \\
Total & 358,080 & 74 & & & \\
\hline
\end{tabular}

a. Dependent Variable: Y

b. Predictors: (Constant), X3, X1, X2

Sumber: Data Primer diolah, 2016

Hasil perhitungan $\mathrm{F}$ hitung diperoleh nilai $\mathrm{F}$ hitung sebesar 10,028 dengan signifikansi sebesar 0,000 lebih kecil dari 0,05 dan F tabel sebesar 2,733. Nilai F sebesar 10,028 > 2,733. Hasil penelitian ini berarti variabel brand image, harga, kualitas produk secara bersama-sama berpengaruh terhadap keputusan pembelian.

\section{Uji t}

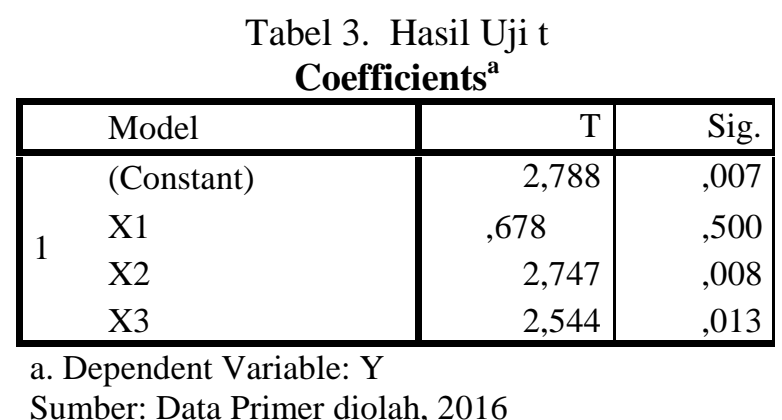

Berdasarkan hasil uji regresi linier berganda menunjukkan bahwa variabel brand image (X1) mempunyai nilai $t_{\text {hitung }}<t_{\text {tabel, }}$ yaitu $0,678<1,993$ dengan taraf signifikansi sebesar 0,500. Artinya, nilai signifikan lebih besar dari 0,05 maka tidak berpengaruh signifikan antara brand image (X1) yang dilakukan terhadap Keputusan Pembelian (Y). 
Variabel Harga (X2) mempunyai nilai $t_{\text {hitung }}>t_{\text {tabel }}$, yaitu 2,747 $>1,993$ dengan taraf signifikansi sebesar 0,008. Artinya, bahwa ada pengaruh positif dan signifikan antara harga (X2) yang dilakukan terhadap Keputusan Pembelian (Y).

Variabel Kualitas Produk (X3) mempunyai nilai $t_{\text {hitung }}>t_{t a b e l}$, yaitu 2,543>1,993 dengan taraf signifikansi sebesar 0,013. Artinya, bahwa ada pengaruh positif dan signifikan antara Kualitas Produk (X3) yang dilakukan terhadap Keputusan Pembelian (Y).

\section{Koefisien Determinasi}

Tabel 4. Koefisien Determinasi

\begin{tabular}{|l|l|l|l|}
\hline Model & $\mathrm{R}$ & $\mathrm{R}$ Square & Adjusted R Square \\
\hline 1 &, $546^{\mathrm{a}}$ &, 298 &, 268 \\
\hline \multicolumn{2}{|c|}{ a. Predictors: (Constant), X3, X1, X2 } \\
\hline \multicolumn{2}{|l|}{ b. Dependent Variable: Y } \\
\hline \multicolumn{2}{|l|}{ Sumber: Data Primer diolah, 2016} \\
\hline
\end{tabular}

Hasil perhitungan koefisien determinasi $\left(\mathrm{R}^{2}\right)$ dengan menunjukkan nilai $\mathrm{R}^{2}=0,298$ Artinya Brand Image (X1), Harga (X2), Kualitas Produk (X3) dapat menerangkan keputusan Pembelian (Y) sebesar 29,8 persen Sisanya 70,2 persen dipengaruhi oleh variabel lain yang tidak termasuk dalam model ini.

Dari hasil penelitian diatas diperoleh beberapa hasil. Hasil Pengujian pertama adalah untuk mengetahui pengaruh Brand Image, Harga, dan Kualitas Produk terhadap Keputusan Pembelian Mobil LCGC di Kota Surakarta secara partial dan bersama-sama. Dalam penelitian ini menunjukkan bahwa secara parsial bahwa variabel brand image (X1) mempunyai nilai $t_{\text {hitung }}<\mathrm{t}_{\text {tabel }}$, yaitu $0,678<1,993$ dengan taraf signifikansi sebesar 0,500. Artinya, nilai signifikan lebih besar dari 0,05 maka tidak berpengaruh signifikan antara brand image (X1) yang dilakukan terhadap Keputusan Pembelian (Y). Responden dalam penelitian ini sebagai konsumen menyatakan bahwa brand image merupakan keyakinan sebagai dalam melakukan keputusan pembelian terhadap merek mobil yang akan dibeli tentang kualitas maupun kesan yang dimiliki terhadap merek mobil tersebut yang diperoleh berdasarkan informasi tentang fakta-fakta yang telah dimiliki oleh konsumen lain yang telah memiliki mobil tersebut. Meskipun demikian brand image yang terdapat dalam penelitian ini tidak mempengaruhi dalam keputusan pembelian mobil LCGC.

Variabel Harga $\left(X_{2}\right)$ secara parsial mempunyai nilai $t_{\text {hitung }}>t_{\text {tabel }}$, yaitu 2,747 $>1,993$ dengan taraf signifikansi sebesar 0,008. Artinya, bahwa ada pengaruh positif dan signifikan antara harga (X2) yang dilakukan terhadap Keputusan Pembelian (Y). Variabel harga mempengaruhi dalam keputusan pembelian, dalam penelitian ini responden sebagai konsumen menyatakan bahwa saat membeli konsumen mobil merek LCGC dapat dijangkau dan sesuai dengan kualitas produknya. Disisi lain harga mobil LCGC merupakan harga yang kompetitif dan sesuai dengan manfaat yang dirasakan oleh konsumen yang telah menggunakan. Harga merek mobil LCGC ini merupakan mobil dengan tema yang dapat dijangkau oleh berbagai elemen masyarakat baik yang berpendapatan yang berbeda-beda. Variabel Kualitas Produk (X3) mempunyai nilai $t_{\text {hitung }}>t_{\text {tabel}}$, yaitu 2,543 > 1,993 dengan taraf signifikansi sebesar 0,013. Artinya, bahwa ada pengaruh positif dan signifikan antara Kualitas Produk (X3) yang dilakukan terhadap Keputusan Pembelian (Y). Variabel kualitas produk tersebut dalam penelitian ini menyatakan bahwa konsumen memiliki keyakinan terhadap produk yang dibeli memberikan rasa nyaman untuk digunakan, mudah dalam perawatannya, mudah dalam memperoleh suku cadang (sparepart) dan mudah dalam menemukan tempat untuk mendapatkan pelayanan bila terjadi kerusakan. Selain itu dari aspek feature mobil merek LCGC adalah mobil yang ramah lingkungan (bahan bakar yang efisien). Konsumen dalam penelitian ini menyatakan bahwa mobil merek LCGC memiliki kecepatan yang sesuai dengan harapan. 
Hasil penelitian dalam menunjukkan secara bersama-sama variabel brand image, harga, kualitas produk secara bersama-sama berpengaruh terhadap keputusan pembelian. Hal ini uji dilihat pada nilai $\mathrm{F}_{\text {hitung }}$ sebesar 10,028 dengan signifikansi sebesar 0,000 lebih kecil dari 0,05 dan $F_{\text {tabel }}$ sebesar 2,733. Nilai F sebesar 10,028 > 2,733.

Hasil pengujian kedua adalah diantara Brand Image, Harga, dan Kualitas Produk mana variabel yang lebih berperan dalam mempengaruhi keputusan pembelian mobil $L C G C$ di Kota Surakarta menunjukkan bahwa variabel Harga (X2) yang memiliki nilai koefisien regresi yang paling besar adalah 0,333 maka varibel harga tersebut merupakan variabel yang sangat mempengaruhi keputusan pembelian mobil LCGC tersebut.

\section{E. PENUTUP}

Berdasarkan hasil penelitian maka dapat disimpulkan beberapa hal. Pertama, terdapat 2 (dua) variabel yang mempengaruhi Keputusan pembelian, yaitu: Harga (X2) dan Kualitas Produk (X3) berpengaruh terhadap keputusan pembelian. Sedangkan variabel Brand Image (X1) tidak berpengaruh terhadap keputusan pembelian. Kedua, Hasil pengujian diperoleh hasil menghasilkan variabel Harga (X2) yang memiliki nilai koefisien regresi yang paling besar maka variabel harga tersebut merupakan variabel yang sangat mempengaruhi keputusan pembelian mobil LCGC tersebut.

Dari hasil penelitian tersebut disarankan agar produsen mobil dan pihak-pihak yang terlibat untuk memperhatikan faktor Harga (X2) dan Kualitas Produk (X3). Selain itu, kepada peneliti selanjutnya agar lebih memperluas variabel yang mempengaruhi sehingga dapat diketahui variabel lain yang mempengaruhi konsumen dalam melakukan penelitian seperti variabel perilaku konsumen, presepsi pelanggan, kinerja, pelayanan, ketahanan, keandalan, dan karakteristik produk yang digunakan.

\section{DAFTAR PUSTAKA}

Angipora, Marius. 2002. Dasar-Dasar Pemasaran. Edisi Kedua. PT. Raja Grafindo Persada. Jakarta.

Bayu Yulianto,2013, Pengaruh Produk, Harga, Promosi, Layanan Terhadap Keputusan Konsumen Membeli Sepeda Motor Kawasaki, Jurnal Ilmu dan Riset Manajemen, Volume 1 Nomor 1,Halaman 25-46.

Cannon, Joseph P., William D. Perreault Jr. dan Jerome McCarthy. 2008. Alih Bahasa : Diana Angelica dan Ria Cahyani. Pemasaran Dasar-Dasar : Pendekatan Manajerial Global. Buku 2. Edisi 16. Salemba Empat. Jakarta.

Hasan, Ali, 2013. Marketing dan Kasus-kasus Pilihan, CAPS (Center for Academic Publishing Service), Yogyakarta.

Hendra Noky Andrianto, Idris, 2013. Pengaruh Kualitas Produk, Citra Merek, Harga Dan Promosi Terhadap Keputusan Pembelian Mobil Jenis Mpv Merek Toyota Kijang Innova Di Semarang, Diponegoro Journal Of Management, Volume 2, Nomor 3, Halaman 1-10.

Keller, KL. 2003. Strategic Brand Management, Building Measurement and Managing Brand Equity, Upper Sadle River, NJ Pearson Education Internasional.

Kotler, Philip., Armstrong,G. 2008, Prinsip-prinsip Pemasaran, Edisi 12 Jilid 1. Erlangga, Jakarta.

Kotler, Philip dan Kevin Lane Keller. 2009. Alih Bahasa : Benyamin Molan. Manajemen Pemasaran. Edisi Keduabelas. Jilid 1. Cetakan Keempat. PT. Indeks. Jakarta. 
Purwanti, Heri Setiawan, Rohmawati, 2012, Pengaruh Harga Dan Kualitas Produk Terhadap Keputusan Pembelian Motor Honda Matic Beat (Studi Kasus Pada Pt. Nusantara Solar Sakti), Jurnal Ekonomi Dan Informasi Akuntansi (Jenius), Volume 2, Nomor 3, Halaman 260-276.

Sanusi, Anwar, 2012. Metodologi Penelitian Bisnis, Salemba Empat: Jakarta.

Setyo Ferry Wibowo, Maya Puspita Karimah,2012, Pengaruh Iklan Televisi Dan Harga Terhadap Keputusan Pembelian Sabun Lux (Survei Pada Pengunjung Mega Bekasi Hypermall), Jurnal Riset Manajemen Sains Indonesia (JRMSI) ,Volume. 3, No. 1, Halaman 1-15.

Simamora, Bilson. 2001. Remarketing For Business Recovery. Cetakan Pertama, PT Gramedia Pustaka Utama, Jakarta.

Tambunan, Krystia dan Ibnu Widiyanto. 2012. Analisis Pengaruh Citra Merek, Persepsi Kualitas, Dan Harga Terhadap Keputusan Pembelian Bandeng Presto (Studi Kasus pada Konsumen di Bandeng Presto Semarang). Jurnal Manajemen. Vol. 1. No. 2. Hal. 58 - 66. Undip. Semarang.

Tedjakusuma, Ritawati, Sri Hartini dan Muryani. 2001. Analisis Faktor-Faktor yang Mempengaruhi Perilaku Konsumen Dalam Pembelian Air Minum Mineral Di Kotamadya Surabaya. Jurnal Penelitian Dinamika Sosial. Vol. 2. No. 3. Desember. Hal. 48 - 58. Universitas Airlangga. Surabaya.

Tjiptono, Fandy. 2006. Manajemen Jasa. Edisi Keempat. Andi. Yogyakarta.

Tjiptono, Fandi, Chandra.G. 2012. Pemasaran Strategik, Edisi 2, Andi Offset, Yogyakarta.

Umar, Husain. 2003. Metode Riset Perilaku Organisasi. Jakarta: PT. Gramedia Pustaka Utama. 